Ilmenau University of Technology

Institute of Economics

Ilmenau Economics Discussion Papers, Vol. 21, No. 109

Four Cases in Sports Competition Policy: Baseball, Judo, Football, and Motor Racing

Oliver Budzinski

September 2017

Institute of Economics

Ehrenbergstraße 29

Ernst-Abbe-Zentrum

D-98 684 Ilmenau

Phone 03677/69-4030/-4032

Fax 03677/69-4203

http://www.wirtschaft.tu-ilmenau.de

ISSN 0949-3859 


\title{
Four Cases in Sports Competition Policy: Baseball, Judo, Football, and Motor Racing
}

\section{Oliver Budzinski}

\begin{abstract}
Practices and conducts in professional and even amateur sports can be subject to competition laws as soon as commercial activities are involved. From an economic perspective, this implies that both directly commercial activities like the sale of broadcasting/media rights and indirectly commercial activities like defining and enforcing the rules of the games can be hit by competition policy interventions. Setting and enforcing the rules of the game is an activity with commercial effects because it influences attractiveness and marketability of the sports in question. After discussing fundamental issues, this contributions reviews selected landmark cases in sports competition policy from an economic perspective. This includes the U.S. baseball antitrust exemption, access rules to Judo tournaments, sale systems of media rights in European football as well as a unique combination of long-run exclusivity contracts, skewed allocation of common revenues, and special influences on rule-setting by some competitors in Formula One motor racing. Eventually, the areas of state aid to football clubs and mergers in Danish football are sketched.
\end{abstract}

Keywords: sports economics, antitrust, competition policy, baseball, judo, football, soccer, motor racing, formula one, media rights, sports broadcasting, competitive balance, cartels, abuse of dominance

JEL-Codes: K21, L40, Z20, L83, L82

Professor of Economic Theory, Institute of Economics, Institute of Media and Mobile Communication, Ilmenau University of Technology, Germany, email: oliver.budzinski@tu-ilmenau.de. The author thanks Annika Stöhr and Milan Lange for valuable editorial assistance. A significantly shorter and considerably revised version will be published in the Sage Handbook of Sports Economics. 


\section{Introduction: Why, When, and How Do Competition Rules Apply to Sports?}

The virtue of competitive markets is the decentralized coordination mechanism, driving supply and demand towards each other. All kinds of influences and shocks drive individual supply and demand plans away from each other but through market competition permanent coordination is inherently provided. As a consequence, competitive markets coordinate economic relations and while doing so promote efficiency of (i) allocation (static welfare), (ii) innovation (dynamic welfare) as well as (iii) reactive capacity (evolutionary welfare). Furthermore, competition is simultaneously a precondition and a consequence of the individual freedom to act in economic affairs (freedom of consumption choice, freedom of supply). However, competitive markets can only be workable and effective if anticompetitive arrangements and conduct by the market participants undermining competition forces is prevented. ${ }^{1}$ It is the task of competition policy to combat and deter anticompetitive arrangements and conduct from within the market. The vast majority of countries in the world have implemented competition policy regimes, some more than hundred years ago, some during the last two decades (Budzinski 2008). Virtually all of them include three fundamental elements: (i) combating anticompetitive cartels and cartel-like arrangements, (ii) controlling monopolists and dominant companies, at least combating the abuse of market power, and (iii) limiting market concentration by controlling mergers and acquisitions for anticompetitive effects. Some additionally seek to combat (however defined) unfair business practices from nonmarket powerful companies or engage in consumer protection regulation. Eventually, the international competition policy regime of the European Union additionally combats anticompetitive state aid for companies competing in the common market.

Generally speaking, competition policy addresses all types of commercial activities and, thus, all industries and businesses within an economy. Sport is no exception as soon as it involves commercial activities. Their existence is obvious from an eco-

Additionally, there are some institutional preconditions for workable markets like property rights definition and enforcement as well as the absence of market external (for instance, governmental) torpedoing of competition. 
nomic perspective if we look into professional sports that often is a billion dollar business: for instance, revenues of the American National Football League (NFL) and the English Premier League were 13 bn US\$ (2015) and 4.838 bn $€$ (2014/2015) respectively. The economic impact of sport on the European Union' economy sums up to almost 4 per cent of GDP and more than 5 per cent of the labor force. ${ }^{2}$ Beyond clear-cut cases, however, it is difficult to exactly delineate commercial sports business from non-commercial sporting activities like grassroots sports conducted by people in their leisure time. Between these two extremes, a large variety of semi-professional and semi-commercial sports exists and it may require a case-by-case assessment whether they should be subject to competition policy or not. For instance, a recent controversy revolved around US college sports, which tends to view itself to be an amateur, non-commercial sport, but which creates considerable monetary turnover - and, thus, was found to be subject to competition rules and policy in several recent court decisions. If any given sports has a relevant commercial side, then every activity affecting its commercial performance may be subject to competition policy, irrespective whether this activity is directly commercial itself (like the sale of media rights) or 'just' influences the attractiveness of the sport for spectators (like a change in the sporting rules).

However, what about the special characteristics of sports, in particular the need for cooperation among the competitors that is of constituting character for sports economics as a discipline (Rottenberg 1956; Neale 1964)? In order to set up a championship or league as a marketable product, the competitors in the sport market must cooperate on the rules of the game, the schedule, enforcement, etc. In economic language this implies that a governance structure with market-internal institutions (rules of the game) that are enforced by a market-internal regulator is required. The market-internal institutions virtually always affect competition - regardless of whether they are of sporting nature (like the dimensions of a football goal or the number of participants and the conditions of their qualification) or commercial at heart (like the marketing of the championship brand or the sale of media rights). In contrast to most other industries, the market-internal regulators

2 See http://ec.europa.eu/competition/sectors/sports/overview_en.html (2017-05-29). 
enjoy comprehensive power: they, inter alia, set and enforce the rules of the game, limit and control participation (market entry), market the common product (inter alia, bundling and selling broadcasting rights), and organize the sharing, distributing and re-allocation of revenues. Thus, the market-internal regulator combines championship management with government-like regulation. While this would be viewed to be blatantly anticompetitive and against fundamental market economy principles in virtually every other industry, the existence of the market-internal regulators and institutions is essential for the business of professional sports since cooperation on rules among the participants is elementary for the common product to be produced. Thus, on the one hand, they are constitutive for establishing sports market competition and, at the same time, restrict competition. From a competition policy perspective, this turns the antitrust evaluation of changes in the market-internal institutions or practices by market-internal market regulators into a challenging task.

The role of the market-internal regulator is particularly delicate because it usually finds itself in a monopoly(-like) position. The majority of professional sports organizes itself in a way that there is one single championship, tournament, or league at the top level. ${ }^{3}$ Such an organization promotes consumer (fan) welfare by offering a competition of the best teams, athletes, etc. and allows to identify the very best, which is - next to the top sports quality (including athletic prowess) - an important motivation for sports consumption. ${ }^{4}$ At the same time, the monopoly position of the sports association creates market power that may be abused at the detriment of customers (high prices, reduced quantities) but also participants (player wages, market entry, cheerleader compensation, etc.). If the participants directly control the market-internal regulator, for instance when the teams of a league form and own the sports association, then anticompetitive conduct origins from cartelization (i.e. the competitors colluding on parameters of competition). If the participants' control of the market-internal regulator is not existent or so indirect that it is inef-

3 A prominent exception would be commercial boxing.

4 While most sports economists would subscribe to the single entity concept, Ross (1989) emphasizes the virtues of a competition among championships in the same sports discipline. 
fective, then the sports 'authority' represents a monopolistic bottleneck with vertical market power (see for more details Budzinski \& Szymanski 2015). In any case, again, the market power is inevitable and cannot be prevented but, at the same time, it may create antitrust problems. Notwithstanding, a general market failure of sports markets cannot be identified from an economic perspective and as such no sector regulation replacing 'ordinary' competition policy is required.

Competition policy is inevitably an endeavor in law and economics. While its goals are economic at heart - protecting the competitive process - its codification and means are law. Logically, the actual law may fit to or deviate from the underlying economics. Therefore, competition policy in sports markets depends on the respective national (or supra-national in the EU case) law and its enforcement. In other words, anticompetitive practices that should fall under the rule of competition law from an economics perspective may be exempted in a given jurisdiction or vice versa. So, while from an economic perspective sports markets are subject to competition policy, they are still characterized by special features that complicate the competition policy assessment of cases in question and, furthermore, their actual treatment depends on the competition law regime of the competent jurisdiction. The paper exemplary addresses competition policy issues in sports markets. First, section 2 deals with a famous antitrust exemption for professional sports in the U.S. Then, section 3 discusses how sports rules, the rule of the game, may be a relevant competition policy issue against the background of a European case. Section 4 analyzes a common cartel in sports market and section 5 describes a particular complex recent case of cartelization and abuse of dominance. Eventually, section 6 lists some more of the common antitrust cases in sports. Since this chapter is economic in nature, it cannot give a comprehensive overview on sports-related competition law and case law (see for overviews Pelnar 2007; Papaloucas 2008). ${ }^{5}$ Instead, it aims to reveal the economic line of reasoning underlying the selected sports antitrust cases and provide a critical discussion of them.

Budzinski (2012: 66-71) provides a comprehensive list of antitrust and competition policy cases in sports markets in the European Union. 


\section{The Baseball Antitrust Exemption in the U.S.}

Probably, the most famous sports-related antitrust exemption relates to Baseball in the U.S. Baltimore Baseball Club of the Federal League brought antitrust action against the National League and the American League in 1922, claiming attempted monopolization of professional baseball in the U.S. and restrictions of trade, for instance, by the implementation of the so-called reserve clause ${ }^{6}$. However, the Supreme Court ruled that US antitrust laws are not applicable to professional baseball because it was not viewed to be commercial and because of competitive balance considerations, i.e. the anticompetitive structures were deemed to be necessary in order to make it a commercial success. ${ }^{7}$ Since then, professional baseball, most notably Major League Baseball (MLB), enjoys a comprehensive antitrust exemption in the U.S.

From an economic perspective, this exemption can hardly be justified. Not only does it seem to be inappropriate nowadays to claim a non-commercial character of MLB in the face of annual revenues in excess of 8bn US\$. Even though these numbers had been much lower in the 1920s, the judgment itself reasoned that restrictive practices by the leagues were necessary to make the game more attractive and the success of the clubs more certain, thus, reverting to commercial reasoning. Furthermore, the strange situation results than one of the U.S. major leagues is exempted from antitrust (baseball), whereas the others are not (football, basketball) (Classen 1988: 369). Not surprisingly, many authors argue that several of the current arrangements in U.S. baseball are anticompetitive in nature and increase ticket and broadcasting prices as well as deter market entries and further cement com-

$6 \quad$ The reserve clause assigned far-reaching rights to the clubs regarding players, even after their contract had expired. It was part of the instruments allegedly used to protect the major leagues against upcoming minor leagues, their clubs or their players (Classen 1988; Brand \& Giorgione 2003).

7 "If the reserve clause did not exist, the highly skillful players would be absorbed by the more wealthy clubs, and thus some clubs in the league would so far outstrip others in playing ability that the contests between the superior and inferior clubs would be uninteresting, and the public would refuse to patronize them. By means of the reserve clause and provisions in the rules and regulations, said one witness, the clubs in the National and American Leagues are more evenly balanced, the contests between them are made attractive to the patrons of the game, and the success of the clubs more certain." (National League of Professional Baseball Clubs v. Federal Baseball Club of Baltimore, Inc., 269 F. 681, 687; D.C. Cir. 1920; cited after Mehra \& Zuercher 2006: 1506). 
petitive advantages of the bigger incumbents, for instance, by blocking MLB teams with smaller markets to relocate to bigger and more profitable markets (inter alia, Hamilton 1998; Mehra \& Zuercher 2006; Mozes \& Glicksman 2011). These severe restrictive effects are hardly outweighed by claimed benefits like financial contributions to minor leagues (Grow 2012), which supposedly should be possible with less restrictive practices as well.

Competitive balance considerations also represent a difficult justification for the MLB antitrust exemption. First, their economic virtue is controversial at best (literature overview: Pawlowski \& Nalbantis 2017). Second, there are several competitive balance enhancing regulations that are less restrictive in competition terms. Third, instead of granting an overall exemption, the nature of the competitive balance problem would be more adequately treated by examining a specific practice by the market-internal regulator and weighing its beneficial and restrictive effects.

\section{The Judo Case: Abuse of Market Power?}

Since sports association by their nature as a market internal regulator enjoy a dominant position, their actions may be suspicious regarding an abuse of market power. While this is obvious if they engage in commercial activities like selling media rights (see section 4), it also extends to their core 'business': setting and enforcing the rules of the games. Even decisions that may appear to be purely sporting at first sight may actually include commercial calculus. For instance, the world football association FIFA changed the specifications of the football in time for the world championship tournament in South Africa (2010). The competition ball was made harder so that it would make the job of the goalkeepers more difficult, thus leading to more goals, thus making the sport more attractive - and more attractive implies economically more successful. Similarly, attempts to make sports more televisionfriendly in order to increase demand and revenues from media represents examples where ostensibly purely sporting rules are shaped according to commercial considerations. Many recent changes in the combating rules but also in the points system of Judo enacted by the International Judo Federation (IJF), for instance, were clearly motivated by the desire to enhance the TV-attractiveness of Judo. And it is no 
stretch to assume that also the enforcement of rules may be subject to commercial considerations.

Among the core sporting tasks of sports associations lies the definition of the number of participants in premier-level tournaments and the selection criteria. Logically, it is impossible to have open top-level championships in most sports, so some limitation - and subsequently the implementation of a selection system - is necessary. Notwithstanding, limiting the participants of premier-level championships represents (i) an artificial reduction of quantity and (ii) the deterrence of a number of wannabe-participants from the commercially most attractive tournaments. Both are typical abuse-strategies of market dominators and monopolies. Still, they are necessary in sports market to some extend - but, of course, may also be abusively exaggerated (Grow 2015: 604-614).

In February 1996, Christelle Deliège, a Belgian Judo fighter in the under 52 kg-class, was prevented from participating in the prestigious Paris International Judo Tournament, a tournament where qualification points for the 1996 Atlanta Olympic games could be obtained. Obviously, for Deliège such participation would have been extremely relevant - not only career-wise but also commercially. ${ }^{8}$ However, her home sports association, the Ligue Belge de Judo (LBJ) nominated two other athletes for the Paris tournament. According to rules implemented by the European Judo Union (EJU), each national federation was limited to a maximum of two judoka per weight class for such qualification tournaments as the one in Paris. Christelle Deliège contested (i) the EJU-quota as being unnecessary restrictive and (ii) the selection decision of the LBJ as being based on non-objective, intransparent criteria. The involved sports associations, in contrast, disputed the economic relevance of their selection decisions (because according to their definition Judo was an amateur sport) and insisted on their autonomy in such decisions.

8 Up to this point, Christelle Deliège had won several times the Belgian championships in her class as well as once the European championship and the under-19 world championship. Thus, she clearly does not represent some random judoka wanting to fight beyond her sporting scope. 
However, the European Court of Justice $(E C J)^{9}$ ruled that sporting rules including participation and qualification rules fall under the jurisdiction of business and competition law and "the mere fact that a sports association or federation unilaterally classifies its members as amateur athletes does not in itself mean that those members do not engage in economic activities within the meaning of Article 2 of the Treaty" (ECJ 2000, para 46). The ECJ gave the opinion that premier-level sport usually involves economic activities (sponsorships, advertising revenues, media revenues, ticket sales, grants for athletes, etc.). However, it also ruled that selection systems for premier-level competitions are not per se a violation of law as long as they are inherent to the organization of sport (ECJ 2000, para 69). However, a specific shape of a selection system may still be unnecessary restrictive. Furthermore, qualification tournaments for the Olympic Games are not events between national teams (ECJ 2000, para 44), so that a selection based upon nationality quotas is not self-evident.

From an economic perspective, the Deliège case (which enjoys an important role as a precedent in law; Bell \& Turner-Kerr 2002) is not only interesting because of its clarification that high-level sports usually involve economic activities. Instead, the questions brought up by the national court about the selection system applied in Judo are sports economic at heart: how to evaluate the trade-off between the softening and biasing effect on competition - here from artificial quantity reduction and access deterrence - and the specific requirements and characteristics of sports - here the necessity to limit participation in premier-level Judo tournaments? From an economics perspective, this trade-off requires that access rules and selection systems must be designed so that they minimize the (inevitable) competitionlessening effects as much as possible. When sports associations define participation, selection and qualification systems and criteria, they (inevitably) enjoy monopoly power. Thus, they must be careful not to abuse this power. This can best be safeguarded by objective and transparent qualification, selection, as well as promotion and relegation (regarding leagues) criteria. For instance, participation in prem-

The case was referred to the ECJ by a national court (the Tribunal de Première Instance de Namur, Belgium) for obtaining an opinion. 
ier-level competitions could be open to anyone satisfying objective requirements in terms of sporting skills. Alternatively, if too many athletes/teams would meet this criterion, a selection based on objective and transparent performance criteria would be acceptable as well. However, scope for associations to select athletes/teams based upon non-objective or intransparent, arbitrary or discretionary criteria represents an anticompetitive abuse of power from an economic perspective. Moreover, the total number of participants must not be unnecessary restrictive, i.e. there must be reasons inherent to the nature of the respective sports for any given limitation of athletes or teams allowed to participate.

Obviously, closed leagues represent an issue according to this line of reasoning as they deter outside teams from participating in a commercially lucrative league on non-performance-related grounds. For instance, even a better performing, better managed, more fan-attractive team cannot enter the closed league on merit of its performance. ${ }^{10}$ More difficult to evaluate is whether top-level sports leagues really allow as much teams to compete as it would be inherent to the sports in question. Do U.S. major leagues really exploit the maximum participant numbers (skeptical: Grow 2015: 604-614)? Are 18 teams (like in the German Bundesliga) for a European-style football league a necessary limitation or unnecessary restrictive? What about 20 teams like in the Spanish La Liga or in the English Premier League? Similar reasoning applies to tournaments where individual athletes compete with each other. And what about national quotas for competitions that are not matches between national teams? For instance, two of the top three Judoka in the IJF World Ranking List in the class of men under-100 kg before the 2016 Rio de Janeiro Olympic Games were German. However, due to the selection rules of the Olympic Committee (allowing only one judoka per class per country per sex to compete,

10 Very recently, two lower-tie US soccer clubs (Miami FC of the North American Soccer League) and Kingston Stockade FC of National Premier Soccer League) brought a case against the U.S. Soccer Federation because the absence of a promotion and relegation system deters them from having the sporting and commercial option to enter higher league levels on sporting performance grounds. (At present, the only way to gain entry to Major League Soccer, North America's top league, is by paying about $\$ 150$ million and being selected by an expansion committee as a viable location for a new team.) Thus, they are excluded from competing in the commercially most relevant soccer markets in the U.S. (https://www.reuters.com/article/us-soccer-usacas-idUSKBN1AJ2YL; 2017-08-17). 
given that she/he matches some minimum performance requirements), one of them was deterred from competing in Rio, whereas many lower-ranked judoka from other nationalities qualified since they were the best of their countries - despite lower-level performances. According to news reports, there is an even more bizarre case from the Paralympics nomination for Rio 2016 in archery (compound class). Despite being ahead in respect to sporting criteria, including the world ranking list, Vanessa Bui was not nominated because - as the national head coach apparently reasoned - her performance level was slightly dropping during recent tournament finals. The competent association has not defined clear-cut and transparent selection criteria, thus, such more subjective reasoning and assessments decided. The athlete that replaced her in the nominations, coincidentally, was the wife of the team manager. ${ }^{11}$ Do such selection systems and decisions display anticompetitive effects or are they necessary and inherent to the sport in question? Unfortunately, the sports economics literature remains very silent on such questions so far.

Following up on the Deliège and other court rulings ${ }^{12}$, the European Commission developed a procedure that sporting rules and conduct by sports associations may not be restrictive in economic terms unless they (i) pursue a legitimate objective, (ii) its restrictive effects are inherent to the pursuit of that objective, and (iii) proportionate to it (European Commission 2007a, 2007b; Budzinski 2012: 48-51). If these conditions are not met, the rule, arrangement or conduct in question is deemed to be anticompetitive and thus prohibited by competition policy. However, if an $o b$ jective justification exists, i.e. if beneficial effects of the rule or conduct in question outweigh the anticompetitive effects, an exemption from prohibition is possible. Such an exemption usually requires an in-depth analysis and evidence that con-

11 Inter alia, https://www.merkur.de/lokales/fuerstenfeldbruck/skandal-paralympics-olympiabogenschiessen-vanessa-6640925.html or http://www.br.de/themen/sport/inhalt/olympia/paralympics-vanessa-bui-interview-100.html (2017-08-17; 16:04).

12 In 2007, the ECJ confirmed and extended his line of reasoning in the Meca-Medina-case, involving prohibitions to participate because of doping suspicions. It clarified that every area of sports association activity may be subject to competition law according to EU law (Weatherill 2006). Budzinski (2012: 53-55) provides a list of sporting rules that have been evaluated by European competition authorities. 
sumers (fans) enjoy a net benefit from it. Other jurisdictions typically rely upon case-by-case analyses without such detailed guidelines. From an economic perspective, the three conditions (legitimate objective, inherence of restrictive effects, proportionality) of the European Commission fit well to economic reasoning of transparency and of limiting restrictive effects to the necessary minimum (inherence, proportionality), even though the criterion of proportionality may be a bit vague and as minimal as possible would be a preferable concept. It can be questioned, however, whether an additional case-by-case exemption option is really necessary or merely creates scope for anticompetitive lobbyism. ${ }^{13}$

\section{Centralized Sale of Broadcasting Rights: A Hardcore-Cartel against Media and the Fans?}

Sports associations more often than not do not restrict their activities to what is necessary to organize the sport in question. Instead, they often directly engage in commercial activities with the sale of media rights (TV broadcasting, online broadcasting, etc.) in professional ball-game leagues representing a particularly exemplary case. Principally, two different models exist: either every club in the league sells the broadcasting rights individually or all the participants (often plus the competent sports association) sell the rights collectively. Currently, virtually all major professional leagues practice a collective sale of media rights. Until the season 2016/17, the premier-level Spanish European-football league represented a prominent exemption where broadcasting rights were sold individually by the teams.

From the viewpoint of the league and the participating teams, a collective sale is attractive because it creates a monopoly-like situation and consequently results in higher total media revenues (monopoly rent) compared to a situation where the teams compete with each other for broadcasting deals. However, the collective deal may not maximize revenues for each single team: maybe, the most attractive teams could secure even more profitable deals on their own in contrast to less at-

13 For instance, UEFA's so-called Financial Fair Play regulations were exempted simply by a common note from that-time UEFA president Platini and that-time EC-commissioner Almunia despite economic analysis showing that the conditions of inherence and proportionality were hardly met (Budzinski 2014). 
tractive teams. The distributional effect on the teams of the league also depends on how the common revenue is allocated among the teams (Budzinski \& Müller-Kock 2017: 4-6):

- equal allocation, i.e. each team receives the same share of the collective revenue,

- performance-based allocation, i.e. teams receive different shares according to their performance; either better performance implies higher shares or, in a reverse-performance-based system, better performance implies lower shares, and

- brand value-based allocation, i.e. teams with larger fan-base or higher marketing potential (past success, tradition, etc.) receive higher shares.

The non-equal allocations can encompass different degrees of skewness and elements of different types of allocation can be combined. While a brand-value allocation, in tendency, mimics the distributional effects of individual sale systems, the other systems benefit some teams (for instance, less successful teams in systems of equal or reverse-performance-based allocation) at the expense of others (more successful teams). Despite the distributional effects and consequent continuous internal conflicts about the 'right' allocation scheme, the monopoly rent appears to be so attractive that virtually all major professional leagues converted to collective sale systems of media rights in the course of time.

From a competition economics perspective, a collective sale of media rights represents a hardcore cartel where the competitors of a market collude to extract rents from the other market side by increasing prices and limiting output. Usually, the cartelists auction the bundled broadcasting rights (often in one or few exclusive packages) like a monopolist with media companies on the other market side competitively bidding for the rights (Cowie \& Williams 1997). Premier sports represent important content for media companies, considerably influencing their competitiveness (Toft 2006: 3), so their demand is usually relatively price-inelastic. Their desire to 'win' the auction for exclusivity deals with the most attractive sports leagues leads to a dynamic bidding competition, driving up prices. Often, the cartel 
also reduces the number or extent of available rights in order to further increase prices. Bundling broadcasting rights into one monopolistic package may lead to market foreclosure in media markets if only few sports leagues represent premier content. While in the US several major leagues compete with each other for fan attractiveness, in Europe, for instance, European-style football dominates the market. Furthermore, the cartel arrangement can hamper the development of certain sub-markets (e.g. new media markets or other regional markets in order to protect pay-TV revenues). If media companies have to pay a supracompetitive prices for sports broadcasting rights, consumers are indirectly harmed as well. Either media companies need to increase their prices in turn (directly in the case of paid content like Pay-TV or tax-/fee-based content like Public-TV, indirectly in the case of advertised-financed free content where users/viewers will have to endure more advertising ${ }^{14}$ ) or they can spent less money on other sports and non-sports programs. In any case, considerable harm to consumer welfare must be expected.

The welfare effects of collective (or centralized) sale systems of sports media rights have been extensively analyzed in the sports economic literature (Atkinson et al. 1988; Késenne 2000; 2001; 2009; 2014; Falconieri et al. 2004; Palasca 2006; Gürtler 2007; Noll 2007; Peeters 2011; 2012). While there is notable tendency to derive or conclude negative total effects on welfare, some benefits for consumer (fan) welfare are discussed as well:

- competitive balance defense,

- the creation of a single point of sale provides efficiencies by reducing transaction costs for clubs and media companies,

- the creation of a common brand provides efficiencies as it increases recognition and distribution of the product, and enhances its attractiveness for the fans (consumers).

Despite widespread skepticism from the sports economic literature, competition authorities and courts have frequently followed these rationales to grant antitrust exemptions to collective sale systems in sports.

14 On the economics of advertised-financed contents (platform economics) see, inter alia, Anderson \& Gabszwewicz (2006) and Budzinski \& Satzer (2011). 
In the U.S., the "competitive balance argument is the main pro-competitive justification that sports leagues offer to defend agreements otherwise prohibited by antitrust laws" (Mehra \& Zuercher 2006: 1505). This goes back to the famous antitrust exemption for professional baseball (see section 2.1). Since then the competitive balance defense has been brought forward in more than 40 cases in order to justify various restrictions of competition such as cartelization among incumbent league participants to prevent market entry of new investors, granting of regional monopoly privileges (exclusive territories), restricting entry and transfer of players, definition of terms of player employment and (maximum) salaries, or limitations of (live) broadcasting and other media coverage (with detailed case references Mehra \& Zuercher 2006: 1506-1508). Even though courts do not always uphold the competitive balance defense in any single case, they fundamentally "acknowledge that some otherwise anticompetitive restraints may be necessary to encourage competitive balance among the league's teams" (Grow 2015: 590; see also ibid: 589-596; Ross 2003: 576; Mehra \& Zuercher 2006: 1507-1511, 1514).

Interestingly, the important role of the competitive balance defense in antitrust policy contrasts with an increasing skepticism in sports economic literature about its welfare-promoting effects. Even though, competitive balance was originally viewed to be an important driver of audience demand ${ }^{15}$, the empirical literature struggles to find a significant positive effect of more competitive balance on audience demand, both in terms of attendance and TV-viewership. ${ }^{16}$ Furthermore, recent development in sports economics theory also cast doubt on an universal relationship and either point to other relevant factors or a more differentiated view (inter alia, Coates et al. 2014; Humphreys \& Zhou 2015; Budzinski \& Pawlowski 2017; Pawlowski et al. 2017). Therefore, an unconditioned and widespread use of the competitive balance defense to exempt commercial sports from competition law cannot be supported by the state of economics research. And even if competitive balance was accepted as a defense, then it would only be eligible for arrangements that internally allocate the common revenues equally or according to a reverse-

\footnotetext{
15 See generally on demand for sports the overview by Budzinski \& Feddersen (2016).

16 See for a comprehensive literature review Pawlowski \& Nalbantis (2017).
} 
performance system. Performance-based or brand value systems are much more unlikely to create considerable pro-competitive-balance effects. Surprisingly, however, competition authorities who accepted the competitive-balance-defense have usually shied away from setting conditions on the internal allocation mechanism of the collectively earned revenues.

Also in the EU, involved parties have brought forward the competitive balance defense in many competition policy cases on community level (case overview: Budzinski 2012: 66-71). The European Commission and the European courts acknowledged competitive balance justifications in various instances (Ross 2003: 578-580). The Commission's 2007 White Paper and accompanying documents explicitly list the need to preserve competitive balance as a specificity of sports and, thus, a legitimate goal of (restrictive) interventions by sports associations (European Commission 2007a,b; Weatherill 2012). However, the restrictive effects of the intervention must be inherent to pursuing the legitimate objective (preserving or enhancing competitive balance) and proportionate (Budzinski 2012: 49-50). Thus, whether an anticompetitive arrangement or practice by a sports association can be justified by competitive balance considerations is assessed case-by-case. For instance, it was accepted, inter alia, with respect to the implementation of transfer windows or the promotion of home-grown talent (Weatherill 2012) but it was rejected in the majority of cases dealing with joint-selling arrangements of broadcasting rights (European Commission 2003: 164-167).

The single-point-of-sale efficiency defense (Kienapfe/ \& Stein 2007: 11-12) rests on transaction cost reasoning, i.e. having a single point of sale (the cartel) reduces the transaction costs for the buyers (media companies). However, without further qualifications this does not qualify from a competition economics point of view: having a monopoly supplier indeed always reduces transaction costs in the sense that costs of searching and selecting disappear. Still, it reduces welfare because the allocative and dynamic inefficiencies of monopoly (or cartelized supply in general) easily overcompensate the transaction cost decrease. So, there must be some specific aspects of selling a league's or championship's broadcasting rights (European 
Commission 2003: rec. 139-153). The European Commission (2007b: 83) argues in its UEFA Champions League (European football) decision: "[t]he single point of sale enabled the acquisition of coverage for the whole UEFA Champions League season, allowing programming to be planned in advance. (...) [D]ue to the knock-out nature of the UEFA Champions League (...) a broadcaster could not know in advance which clubs would make it through to the end." This reasoning emphasizes the knock-out character (cup system) of the UEFA Champions League (European Commission 2003: rec. 145). And, indeed, it is difficult to sell the coverage of a whole cup in advance with a decentralized system since nobody knows in advance who will survive the knock-out rounds. However, from an economics perspective, it is not clear at all why the complete coverage must be sold in advance of the season and cannot be offered in sequences corresponding to the knock-out rounds (Budzinski 2012: 59-60). Actually, selling broadcasting rights sequentially round-byround at a time, when the respective team pairings are actually known, should lead to a more efficient price of the media rights.

Moreover, the specific reasoning only covers cup systems. However, the European Commission also granted conditional exemption from the cartel prohibition to centralized broadcasting selling systems of the English Premier League and the German Bundesliga (European Commission 2005, 2006) - in both cases with reference to the reasoning of the earlier Champions League decision. Both leagues work with a playing schedule that is fully determined in advance of the season. So, here the single-point-of-sale-defense - which is questionable from an economics perspective anyway - does not apply at all.

Another line of reasoning refers to the efficiency effects of creating a common brand (increasing recognition and distribution of the product). The creation of a coherent league product may increase its attractiveness for the fans (consumers) as the product is focused on the competition as a whole rather than the individual clubs participating in the competition (Kienapfe/ \& Stein 2007: 11-12). Notwithstanding, a joint-selling arrangement would need to be inherent to create a common brand (insofar as this represents a legitimate objective). It is difficult, however, 
to understand why centralized sales systems would be inherent to a common brand, i.e., a common appearance could not be safeguarded otherwise (common design, lower-level contractual obligations to follow certain standards for broadcasting, etc.) in an individualized system, except maybe of the broadcasting of comprehensive highlights programs of match-days (European Commission 2003, rec. 146) - if this is viewed to be an essential service.

Despite the acceptance of the single-point-of-sale defense as well as the commonbrand defense, the European Commission (2007b: 84-89) has established a list of remedies that must be fulfilled in order to exempt joint-selling arrangements from the cartel prohibition:

- non-discriminatory and transparent competitive tendering,

- limitation of the duration of exclusive vertical contracts (max. three seasons), i.e. employing a 'sun-setting mechanism',

- limitation of the scope of exclusive vertical contracts, i.e. unbundling media rights into several separate and meaningful packages in order to prevent market foreclosure,

- exclusion of conditional bidding,

- fall-back option, use obligation and parallel exploitation in order to remedy output restrictions; i.e. unused rights fall back to the individual clubs for parallel, competitive exploitation,

- 'no single buyer obligation' in case of already existing dominance of one television operator, and

- trustee supervision of the tender procedure.

These conditions seek to remedy foreclosure effects on downstream media markets. As such they are certainly quite effective. However, whether they are sufficient to safeguard positive consumer welfare effects is doubtful.

\section{The Formula One Case: Abuse of Market Power Combined with a Cartel?}

In the preceding paragraph, I emphasized the importance of the internal allocation of common revenues from a collective sale of media rights among the participants, 
i.e. the teams, the sports association (internal market regulator), and in some cases an independent promoter. Such a constellation drives one of the most interesting recent competition policy issues in commercial sports - in this case, the FIA Formula One World Championship. ${ }^{17}$ There is a unique element in the governance structure of Formula One: the market-internal regulator, the Fédération Internationale de I'Automobile (FIA), sold the exclusive media and marketing rights to Formula One for a 100-year period (!) for a one-off lump sum price of US\$313.7 million (Sy/t 2014a, b) to a company, Formula One Management (FOM)/Delta Topco, that is independent from both the participating teams and the FIA (until the latter took a 1 per cent minority share in 2014). While the long period is suspicious in itself from a competition economics point of view, it also rather unusual that the participating teams in the sport do not hold any shares in the exclusive promoter. Instead, the commercial rights holder, through a chain of channel island companies, was originally majority-owned by Bernie Ecclestone (a former team boss and long-time ally of that-time FIA president Max Mosley), then by private equity company CVC Capital Partners and since 2016/17 by Liberty Media, with several banks as well as investment and asset management companies as minority shareholders. In most other commercial sports, the media and marketing rights are in the majorityownership of the participants and/or the governing sports association. Eventually, the one-off (!) lump sump price of little more than US\$300 million surprises given an annual (!) profit for the owners of more than US\$500 million in average. So, each year nets significant more profit $(=$ after the teams have been paid their share) into the pockets of the owners than they paid in total for the 100-year contract. This does smell like a supracompetitive rent.

Given the obvious market power generated by 100 years (2010-2110) exclusive media and marketing rights to the worldwide premier motor racing series, the first question relates to a possible abuse of market power vis-à-vis the Formula One teams. While other commercial/professional sports distribute between 90 and 100 per cent of collective media revenues to the participating teams (or other partici-

17 For more details on the overall case and its economic analysis see Budzinski \& Müller-Kock (2017). 
pants), FOM and its owners distributed only 50 to 65 per cent - and pocketed the rest as profits for themselves. In the absence of any economically reasonable procompetitive explanation of the unique high shares to sports-outsider shareholders, an abuse of market power appears to be plausible (Budzinski \& Müller-Kock 2017: 6-9).

However, there is more to this story when looking at the allocation of media revenues among the teams of Formula One. The part of the common revenues that is distributed to the teams is allocated among them according to (i) a performancebased mechanism and (ii) a so-called heritage payment system. The performancebased pillar is organized according to the former-seasons standings of the FIA Formula One World Constructor Championship (WCC), where the teams are ranked according to the points they scored in the races of the season. Here, two aspects stand out. First, the allocation is significantly more top-heavy than in other premier level professional sports, i.e. the top-performing (low-performing) teams receive a comparatively higher (lower) share of the distributed money than in other sports (Budzinski \& Müller-Kock 2017: 13-14). Second, teams outside the top 10 and newcomer teams reportedly do not receive any share at all. Consequently, the system considerably benefits the top teams at the expense of the smaller teams and tends to cement existing competitive advantages and disadvantages, thus lessening competition. This is further fuelled by the heritage payments pillar. These payments go to five teams (2014-2015) because of their special value for Formula One due to historical success (which makes it a special form of a brand value-based system). It is puzzling, however, that the ranking of the payments as well as the selection of the teams does not correspond at all to historical success figures (Budzinski \& Müller-Kock 2017: 15-16). Furthermore, the heritage payment to Ferrari alone was higher than what the WCC-winner received performance-based only. In other words, any non-heritage team could win the WCC and yet would receive less money than Ferrari, even if Ferrari would end up dead-last.

In 2015, this constellation led to an antitrust complaint by two midfield (and nonheritage) teams to the European Commission alleging a cartel among FOM and the 
heritage teams to secure supracompetitive rents and disadvantage non-heritage teams, thus restricting competition. As strange as this may sound at first sight - a promoter cartelizing with selected teams - the special governance structure of Formula One and the actions by the parties stand in line with incentives to form such a cartel (Budzinski \& Müller-Kock 2017: 9-17). The monopoly power and rents for FOM rest on the top teams staying in Formula One and refrain from departing to a breakaway series. Thus, there may be countervailing power for the top teams if they unionize - but none for midfield teams. Theoretically, a cartel (i) securing FOM's rents and (ii) cementing the competitive advantage of the heritage teams ${ }^{18}$ perfectly serves the (anticompetitive) interests of both parties. Moreover, the socalled Steering Group of Formula One could serve as a stabilizing institutional arrangement. It consists of FIA (6 votes), FOM (6 votes), the five heritage teams (one vote each) and one of the non-heritage teams (one vote) and plays the role of a gate-keeper regarding rule-changes in Formula One (Sylt 2014b; Rencken 2015). Consequently, the alleged cartel teams are privileged in the revenue allocation and privileged regarding their influence on rules. Thus, the construction of the Steering Group may help to stabilize the cartel by providing a sanction mechanism devaluating deviation strategies for heritage teams. ${ }^{19}$

The existence of a cartel would explain the persistence of the unique high share of the independent promoter as well as the extraordinary top-heavy character of the performance-based allocation pillar and the difficult-to-explain heritage payment pillar. Interestingly, the two top receivers of the so-called heritage payments have according to reports - been the first to leave a breakaway series threat (mounted by a teams' union) and to sign with FOM again (Rencken \& Barretto 2015; Rencken 2015). Surprisingly, and despite a request of the European Parliament (2017), the European Commission has hitherto not shown any motivation to enter an in-depth investigation into this case.

18 Motor racing is a very technology-focused sport where budget differences matter a lot in terms of competitiveness.

19 If one of them would consider leaving the cartel, rule-changes hurting its competitive position may be enacted by the cartel insiders through the Steering Group (where cartel outsiders and one deviator cannot have a majority of votes). 


\section{Additional Types of Anticompetitive Practices}

The preceding chapter discussed cartelization and abuse of dominance because most competition policy cases in sports fall into these categories. This also includes rules and practices that are designed to enhance competition, like (ticket) revenuesharing arrangements (e.g. NFL, MLB), salary and payroll caps (e.g. NFL, NBA, NHL), direct or indirect budget caps (e.g. UEFA Financial Fair Play regulations), etc., which may under specific conditions in effect distort competition and serve to protect supracompetitive rents (Budzinski 2017). Another frequently occurring concern are exclusivity contracts with equipment suppliers or definitions of equipment standards with foreclosure effects (Lopatka 2009). Merger cases, in contrast, are rather rare. There have been a few mergers between rivaling leagues, for instance, the mergers between the National Football League and the American Football League or between the National Basketball Association and the American Basketball Association in the U.S. (Pelnar 2007). However, despite potentially forming a monopoly, they usually do not trigger antitrust intervention because consumer welfare benefits from having the best competing in the same championship outweigh monopolization concerns, especially given the peculiar organization structure and cooperation requirement of sports (see section 1). Within leagues, mergers between formerly horizontal competitors do raise concerns about a lessening of competition from an economic perspective. Usually, they go hand-in-hand with the disappearance of a direct horizontal competitor because owners are normally not allowed to run several teams in the same league/championship due to concerns for sporting integrity. For instance, the Danish premier level European football league experienced a series of mergers since the 1990s (see table 1) that did not receive much attention in the sports economics literature. 
Table 1: Mergers in Premier-Level Danish Football since 1991

\begin{tabular}{|c|c|c|}
\hline Year & Merging Clubs & New Entity \\
\hline 1991 & Farum IK, Stavnsholt BK & $\begin{array}{l}\text { FC Nordsjælland (until } \\
\text { 2003: Farum BK) }\end{array}$ \\
\hline 1992 & Københavns BK, Boldklubben 1903 & FC København \\
\hline 1994 & Horsens FS, Dagnæs IF, B1940 & AC Horsens \\
\hline 1999 & Ikast FS, Herning Fremad & FC Midtjylland \\
\hline 2005 & $\begin{array}{l}\text { Helsingør IF, Helsingør FC, Frem Hellebæk IF, } \\
\text { Vapnagaard FK72, Snekkersten IF }\end{array}$ & $\begin{array}{l}\text { FC Helsingør (until 2012: } \\
\text { Elite } 3000 \mathrm{FB} \text { ) }\end{array}$ \\
\hline 2006 & B 1909, B1913, Dalum IF & FC Fyn \\
\hline 2008 & $\begin{array}{l}\text { BK Fremad Amager, Dragør BK, Kastrup BK, } \\
\text { Kløvermarken FB }\end{array}$ & FC Amager \\
\hline 2009 & Herfølge BK, Køge BK & HB Køge \\
\hline 2011 & Vejle BK, Kolding FC & Vejle Boldklub Kolding \\
\hline
\end{tabular}

One merger particularly stands out: the merger between Københavns BK (fifteentime Danish champion) and its local arch rival BK 1903 (seven-time Danish champion) created the FC København (Copenhagen FC) who went on to win the Danish Superligaen (the premier-level Danish football league since 1991) immediately in 1992-93 and added eleven more titles since then. Thus, two already market-leading clubs formed a new entity that is basically dominating Danish professional football in the last decade. Some of the other merged entities enjoyed considerably more success than their predecessors. For instance, FC Midtjylland became a frontrunner, winning the championship in 2014-15, whereas the pre-merger clubs had never played a significant role in Danish football. FC Nordsjælland represents a similar example, winning the title in 2011-12. In the last twelve years, only one nonmerged club, Aalborg BK, managed to win Superligaen. On the other hand, FC Amager (2008) and FC Fyn (2013) went into insolvency and the merger Vejle and Kolding was dissolved after only two seasons in June 2013. The case of Danish football could be an interesting case study for the effects of mergers in sports leagues and would warrant a systematic analysis.

In the European Union, the combat of anticompetitive state aid represents a fourth and rather unique pillar of competition policy. This has triggered quite a number of cases where national, regional or local governments have subsidized "their" teams 
with taxpayer money by paying direct grants, financing the arena/stadium or other infrastructure, obliterating debts, abating taxes or granting special tax reliefs, preventing insolvencies, granting payments ostensibly for youth/social work, redirecting state-regulated betting and lottery revenues, etc. (Maria 2007: 291312). ${ }^{20}$ In doing so, they give "their" team a competitive advantage and distort competition. A particular prominent case relates to the top European football club Real Madrid (Gröteke 2004). It signed an agreement with the Mayor of Madrid and the governor of Madrid-region under which the respective administrations changed the classification for planning purposes of land owned by Real Madrid from recreational and parking use to business and commercial use. In doing so, the value of the land sky-rocketed and poured significantly more money into the pockets of Real Madrid - along with a non-negligible competitive advantage (and instant transfer activities to acquire new star players).

\section{References}

Anderson, S. P. \& Gabszewicz, J. (2006), The Media and Advertising: A Tale of TwoSided Markets, in: Handbook of the Economics of Art and Culture, Vol. 1, Amsterdam: Elsevier, pp. 567-614.

Atkinson S., Stanley, L. \& Tschirhart, J. (1988), Revenue Sharing as an Incentive in an Agency Problem: an Example from the National Football League, in: RAND Journal of Economics, Vol. 19 (1), pp. 27-43.

Bell, A. \& Turner-Kerr, P. (2002), The Place of Sport Within the Rules of Community Law: Clarification from the ECJ? The Deliège and Lehtonen Cases, in: European Competition Law Review, Vol. 23 (5), pp. 256-260.

Brand, S. M. \& Giorgione, A. J. (2003), The Effect of Baseball's Antitrust Exemption and Contraction on its Minor League Baseball System: A Case Study of the Harrisburg Senators, in: Villanova Sports \& Entertainment Law Journal, Vol. 10 (1), pp. 49-68.

Budzinski, O. (2008), The Governance of Global Competition, Cheltenham: Elgar.

20 Similar things take place in the U.S. but are not subject to antitrust laws there (Keshock et al. 2014). 
Budzinski, O. (2012), The Institutional Framework for Doing Sports Business: Principles of EU Competition Policy in Sports Markets, in: International Journal of Sport Management and Marketing, Vol. 11 (1-2), pp. 44-72.

Budzinski, O. (2014), The Competition Economics of Financial Fair Play, in: O. Budzinski \& A. Feddersen (eds.), Contemporary Research in Sports Economics: Proceedings of the $5^{\text {th }}$ ESEA Conference, Frankfurt a.M.: Lang, pp. 77-98.

Budzinski, O. (2017), Financial Regulation as an Anticompetitive Institution, Palgrave Handbook on the Economics of Manipulation in Professional Sports, Palgrave, forthcoming.

Budzinski, O. \& Feddersen, A. (2016), Mikroökonomische Aspekte des Spitzensports: Nachfrage I - Einflussfaktoren auf die Zuschauernachfrage, in: C. Deutscher, G. Hovermann, T. Pawlowski \& L. Thieme (Eds.), Handbuch Sportökonomik, Schorndorf: Hofmann-Verlag, pp. 41-65.

Budzinski, O. \& Müller-Kock, A. (2017), Is the Revenue Allocation Scheme of Formula One Motor Racing a Case for European Competition Policy?, in: Contemporary Economic Policy, Vol. 35, forthcoming, doi:10.1111/coep.12247

Budzinski, O. \& Pawlowski, T. (2017), The Behavioural Economics of Competitive Balance - Theories, Findings and Implications, in: International Journal of Sport Finance, Vol. 12 (2), pp. 109-122.

Budzinski, O. \& Satzer, J. (2011), Sports Business and Multisided Markets: Towards a New Analytical Framework?, in: Sports, Business, Management: An International Journal, Vol. 1 (2), pp. 124-137.

Budzinski, O. \& Szymanski, S. (2015), Are Restrictions of Competition by Sports Associations Horizontal or Vertical in Nature?, in: Journal of Competition Law \& Economics, Vol. 11 (2), pp. 409-429.

Classen, H. W. (1988), Three Strikes and You're Out: An Investigation of Professional Baseball's Antitrust Exemption, in: Akron Law Review, Vol. 21 (4), pp. 369-390.

Coates, D., Humphreys, B. \& Zhou, L. (2014), Reference-dependent Preferences, Loss aversion, and Live Game Attendance, in: Economic Inquiry, Vol. 52 (3), pp. 959-973.

Cowie, C. \& Williams, M. (1997), The Economics of Sports Rights, in: Telecommunications Policy, Vol. 21 (7), pp. 619-634. 
ECJ (2000), Judgment 11.4.00 in Joined Cases C-51/96 and C-191/97 „Deliège", Luxembourg.

European Commission (2003), COMP/C.2-37.398 - Joint Selling of the Commercial Rights of the UEFA Champions League, Commission Decision, 2003/778/EC, Brussels.

European Commission (2005), Case COMP/C-2/37.214 - Joint Selling of the Media Rights to the German Bundesliga, Commission Decision, Brussels.

European Commission (2006), COMP/C-2/38.173 - Joint Selling of the Media Rights to the FA Premier League, Commission Decision, C(2006)/868, Brussels.

European Commission (2007a), The White Paper on Sport, COM (2007) 391 final, Brussels.

European Commission (2007b), The EU and Sport: Background and Context, Commission Staff Working paper accompanying the White Paper on Sport, SEC(2007)935, Brussels.

European Parliament (2017), Annual Report on EU Competition Policy. P8_TAPROV(2017)0027, Strasbourg.

Falconieri, S., Palomino, F. \& Sákovics, J. (2004), Collective versus Individual Sale of Television Rights in League Sports, in: Journal of the European Economic Association, Vol. 2 (5), pp. 833-862.

Gröteke, F. (2004), Zur Frage der Behandlung von Regulierungen in der Beihilfenkontrolle und mögliche Konsequenzen des Grundstücksverkaufs von Real Madrid, in: Finanzreform, Vol. 1 (11), pp. 146-159.

Grow, N. (2012), In Defense of Baseball's Antitrust Exemption, in: American Business Law Journal, Vol. 49 (2), pp. 211-273.

Grow, N. (2015), Regulating Professional Sports Leagues, in: Washington and Lee Law Review, Vol. 72 (2), pp. 573-652.

Gürtler, O. (2007), A Rationale for the Coexistence of Central and Decentral Marketing in Team Sports, in: German Economic Review, Vol. 8 (1), pp. 89-106.

Hamilton, J. (1998), Congress in Relief: The Economic Importance of Revoking Baseball's Antitrust Exemption, in: Santa Clara Law Review, Vol. 38 (4), pp. 1223-1254. 
Humphreys, B. R. \& Zhou, L. (2015), The Louis-Schmeling Paradox and the League Standing Effect Reconsidered, in: Journal of Sports Economics, Vol. 16 (8), pp. 835-852.

Késenne, S. (2000), Revenue Sharing and Competitive Balance in Professional Team Sports, in: Journal of Sports Economics, Vol. 1 (1), pp. 56-65.

Kesenne S. (2001), The Different Impact of Different Sharing Systems on the Competitive Balance in Professional Team Sports, in: European Sports Management Quarterly, Vol. 1 (3), pp. 210-218.

Késenne, S. (2009), The Impact of Pooling and Sharing of Broadcasting Rights in Professional Team Sports, in: International Journal of Sport Finance, Vol. 4 (3), pp. 211-218.

Késenne, S. (2014), The Collection and Distribution of Media Rights in a Winmaximization League, in: J. Goddard \& P. Sloane (Eds.), Handbook on the Economics of Professional Football, Cheltenham: Elgar, pp. 73-79.

Keshock, C. M., Forester, B. \& Holden, S. (2014), Gridiron Games - A Case Analysis of Turf War Issues and the Economic, Social, Cultural, and Political Incentives for Government Subsidization, in: O. Budzinski \& A. Feddersen (eds.), Contemporary Research in Sports Economics: Proceedings of the $5^{\text {th }}$ ESEA Conference, Frankfurt a.M.: Lang, pp. 231-244.

Kienapfel, P. \& Stein, A. (2007), The Application of Articles 81 and 82 EC in the Sport Sector, in: Competition Policy Newsletter, No. 3, pp. 6-14.

Lopatka, J. E. (2009), Antitrust and Sports Equipment Standards, in: The Antitrust Bulletin, Vol. 54 (4), pp. 751-800.

Maria, A. S. (2007), Competition and State Aid, Amsterdam: Kluwer.

Mehra, S. K. \& Zuercher, T. J. (2006), Striking Out Competitive Balance in Sports, Antitrust, and Intellectual Property, in: Berkeley Technology Law Journal, Vol. 21 (4), pp. 1499-1545.

Mozes, M. J. \& Glicksman, B. (2011), Adjusting the Stream-Analyzing Major League Baseball's Antitrust Exemption after American Needle, in: Harvard Journal of Sports and Entertainment Law, Vol. 2 (2), pp. 265-296. 
Neale, W. C. (1964), The Peculiar Economics of Professional Sports: a Contribution to the Theory of the Firm in Sporting Competition and in Market Competition, in: Quarterly Journal of Economics, Vol. 78 (1), pp. 1-14.

Noll, R. G. (2007), Broadcasting and Team Sports, in: Scottish Journal of Political Economy, Vol. 54 (3), pp. 400-421.

Palasca, S. (2006), Collective Selling of Broadcasting Rights in Team Sports, in: W. Andreff \& S. Szymanski (eds.). Handbook on the Economics of Sport. Cheltenham: Elgar, pp. 719-729.

Papaloucas, M. (2008), Sport: Case Law, http://ssrn.com/abstract=1311952.

Pawlowski, T. \& Nalbantis, G. (2017), Competitive Balance: Measurement and Relevance, in: Handbook of Sports Economics, Sage Publications, forthcoming.

Pawlowski, T., Nalbantis, G. \& Coates, D. (2017), Perceived Game Uncertainty, Suspense and the Demand for Sport, in: Economic Inquiry, forthcoming, doi 10.1111/ecin.12462.

Peeters, T. (2011), Broadcasting Rights and Competitive Balance in European Soccer, in: International Journal of Sport Finance, Vol. 6 (1), pp. 23-39.

Peeters, T. (2012), Media Revenue Sharing as a Coordination Device in Sports Leagues, in: International Journal of Industrial Organization, Vol. 30 (2), pp. 153163.

Pelnar, G. (2007), Antitrust Analysis of Sports Leagues, https://ssrn.com/abstract $=1021365$.

Rencken, D. (2015), The Story Behind F1's Financial Structure, in: Autosport, 2015, http://plus.autosport.com/premium/feature/6511/the-story-behind-f1-financialstructure?_ga=1.105073923.1023793221.1375981403, (2015-05-14; 13:42).

Rencken, D. \& L. Barretto (2015), Details of Formula 1 Teams' 2014 Payout Revealed, in: Autosport, 2015, http://www.autosport.com/news/report.php/id/118955 (2015-10-05).

Ross, S. F. (1989), Monopoly Sports Leagues, in: Minnesota Law Review, Vol. 73 (3), pp. 643-761.

Ross, S. F. (2003), Competition Law as a Restraint on Monopolistic Exploitation by Sports Leagues and Clubs, in: Oxford Review of Economic Policy, Vol. 19 (4), pp. 569-584. 
Rottenberg, S. (1956), The Baseball Player's Labour Market, in: Journal of Political Economy, Vol. 64 (3), pp. 242-258.

Sylt, C. (2014a), How CVC Has Made \$8.2 Billion from Formula One Auto Racing, in: Forbes Online, http://www.forbes.com/sites/csylt/2014/04/15/how-cvc-has-made8-2-billion-from-formula-one-auto-racing/\#202bf8ab61d7 and http://www.forbes.com/sites/csylt/2014/04/15/how-cvc-has-made-8-2-billionfrom-formula-one-auto-racing/2/\#a99f50a59ee9 (2016-06-08).

Sylt, C. (2014b), European Commission Investigating F1 Anti-Competition Allegations, in: Forbes Online, http://www.forbes.com/sites/csylt/2014/11/26/europeancommission-investigating-f1-anti-competition-allegations/ (2015-10-25; 14:50).

Toft, T. (2006), Developments in European Law, Congress Sports \& Law, Berlin.

Weatherill, S. (2006), Anti-doping Revisited: The Demise of the Rule of "Purely Sporting Interest"?, in: European Competition Law Review, Vol. 27, pp. 645-657.

Weatherill, S. (2012), EU Sports Law: The Effect of the Lisbon Treaty, in: A. Biondi, P. Eeckhout \& S. Ripley (eds.), EU Law after Lisbon, Oxford: Oxford University Press, pp. 403-420. 


\section{Diskussionspapiere aus dem Institut für Volkswirtschaftslehre der Technischen Universität IImenau}

Nr. 49 Jaenichen, Sebastian; Steinrücken, Torsten: Opel, Thüringen und das Kaspische Meer, Januar 2006.

Nr. 50 Kallfaß, Hermann H.: Räumlicher Wettbewerb zwischen Allgemeinen Krankenhäusern, Februar 2006.

Nr. 51 Sickmann, Jörn: Airport Slot Allocation, März 2006.

Nr. 52 Kallfaß, Hermann H.; Kuchinke, Björn A.: Die räumliche Marktabgrenzung bei Zusammenschlüssen von Krankenhäusern in den USA und in Deutschland: Eine wettbewerbsökonomische Analyse, April 2006.

Nr. 53 Bamberger, Eva; Bielig, Andreas: Mehr Beschäftigung mittels weniger Kündigungsschutz? Ökonomische Analyse der Vereinbarungen des Koalitionsvertrages vom 11. 11. 2005, Juni 2006.

Nr. 54 Jaenichen, Sebastian; Steinrücken, Torsten: Zur Ökonomik von Steuergeschenken - Der Zeitverlauf als Erklärungsansatz für die effektive steuerliche Belastung, Dezember 2006.

Nr. 55 Jaenichen, Sebastian; Steinrücken, Torsten: Wirkt eine Preisregulierung nur auf den Preis? Anmerkungen zu den Wirkungen einer Preisregulierung auf das Werbevolumen, Mai 2007.

Nr. 56 Kuchinke, B. A.; Sauerland, D.; Wübker, A.: Determinanten der Wartezeit auf einen Behandlungstermin in deutschen Krankenhäusern - Ergebnisse einer Auswertung neuer Daten, Februar 2008.

Nr. 57 Wegehenkel, Lothar; Walterscheid, Heike: Rechtsstruktur und Evolution von Wirtschaftssystemen - Pfadabhängigkeit in Richtung Zentralisierung?, Februar 2008.

Nr. 58 Steinrücken, Torsten; Jaenichen, Sebastian: Regulierung und Wohlfahrt in einem Modell mit zwei Aktionsparametern, März 2008.

Nr. 59 Lehnert, Ninja M.: Externe Kosten des Luftverkehrs - Ein Überblick über den aktuellen Stand der Diskussion, April 2008.

Nr. 60 Walterscheid, Heike: Reformbedarf etablierter Demokratien im Kontext dezentralisierter Gesellschaftssysteme - Grundlegende Hindernisse bei Steuersystemreformen", April 2010. 
Nr. 61 Walterscheid, Heike; Wegehenkel, Lothar: Kostenstruktur, Zahlungsbereitschaft und das Angebot von Mediengütern auf Medienmärkten, Juni 2008.

Nr. 62 Walterscheid, Heike; Wegehenkel, Lothar: Wohlstand der Nationen und handlungsrechtliche Struktur eines Gesellschaftssystems, September 2008.

Nr. 63 Dewenter, Ralf; Haucap, Justus; Wenzel, Tobias: Indirect Network Effects with Two Salop Circles: The Example oft the Music Industry, Juni 2009.

Nr. 64 Dewenter, Ralf; Jaschinski, Thomas; Wiese, Nadine: Wettbewerbliche Auswirkungen eines nichtneutralen Internets, Juli 2009.

Nr. 65 Dewenter, Ralf; Haucap, Justus; Kuchinke, Björn A.: Das Glück und Unglück von Studierenden aus Ost- und Westdeutschland: Ergebnisse einer Befragung in Ilmenau, Bochum und Hamburg, Oktober 2009.

Nr. 66 Kuchinke, Björn A.; Zerth, Jürgen; Wiese, Nadine: Spatial Competition between Health Care Providers: Effects of Standardization, Oktober 2009.

Nr. 67 Itzenplitz, Anja; Seifferth-Schmidt, Nicole: Warum Klimakonferenzen scheitern, aber dennoch zum Wohl des Weltklimas kooperiert wird, Juli 2010.

Nr. 68 Kallfaß, Hermann H.: Die Aufmerksamkeit für, die Nutzung der und die Werbung in Medien in Deutschland, November 2010.

Nr. 69 Budzinski, Oliver: Empirische Ex-Post Evaluation von wettbewerbspolitischen Entscheidungen: Methodische Anmerkungen, Januar 2012.

Nr. 70 Budzinski, Oliver: The Institutional Framework for Doing Sports Business: Principles of EU Competition Policy in Sports Markets, January 2012.

Nr. 71 Budzinski, Oliver; Monostori, Katalin: Intellectual Property Rights and the WTO, April 2012.

Nr. 72 Budzinski, Oliver: International Antitrust Institutions, Juli 2012.

Nr. 73 Lindstädt, Nadine; Budzinski, Oliver: Newspaper vs. Online Advertising Is There a Niche for Newspapers in Modern Advertising Markets?

Nr. 74 Budzinski, Oliver; Lindstädt, Nadine: Newspaper and Internet Display Advertising - Co-Existence or Substitution?, Juli 2012b.

Nr. 75 Budzinski, Oliver: Impact Evaluation of Merger Control Decisions, August 2012. 
Nr. 76 Budzinski, Oliver; Kuchinke, Björn A.: Deal or No Deal? Consensual Arrangements as an Instrument of European Competition Policy, August 2012.

Nr. 77 Pawlowski, Tim, Budzinski, Oliver: The (Monetary) Value of Competitive Balance for Sport Consumers, Oktober 2012.

Nr. 78 Budzinski, Oliver: Würde eine unabhängige europäische Wettbewerbsbehörde eine bessere Wettbewerbspolitik machen?, November 2012.

Nr. 79 Budzinski, Oliver; Monostori, Katalin; Pannicke, Julia: Der Schutz geistiger Eigentumsrechte in der Welthandelsorganisation - Urheberrechte im TRIPS Abkommen und die digitale Herausforderung, November 2012.

Nr. 80 Beigi, Maryam H. A.; Budzinski, Oliver: On the Use of Event Studies to Evaluate Economic Policy Decisions: A Note of Caution, Dezember 2012.

Nr. 81 Budzinski, Oliver; Beigi, Maryam H. A.: Competition Policy Agendas for Industrializing Countries, Mai 2013.

Nr. 82 Budzinski, Oliver; Müller, Anika: Finanzregulierung und internationale Wettbewerbsfähigkeit: der Fall Deutsche Bundesliga, Mai 2013.

Nr. 83 Doose, Anna Maria: Methods for Calculating Cartel Damages: A Survey, Dezember 2013.

Nr. 84 Pawlowski, Tim; Budzinski, Oliver: Competitive Balance and Attention Level Effects: Theore-tical Considerations and Preliminary Evidence, März 2014.

Nr. 85 Budzinski, Oliver: The Competition Economics of Financial Fair Play, März 2014.

Nr. 86 Budzinski, Oliver; Szymanski, Stefan: Are Restrictions of Competition by Sports Associations Horizontal or Vertical in Nature?, März, 2014.

Nr. 87 Budzinski, Oliver: Lead Jurisdiction Concepts Towards Rationalizing Multiple Competition Policy Enforcement Procedures, Juni 2014.

Nr. 88 Budzinski, Oliver: Bemerkungen zur ökonomischen Analyse von Sicherheit, August 2014.

Nr. 89 Budzinski, Oliver; Pawlowski, Tim: The Behavioural Economics of Competitive Balance: Implications for League Policy and Championship Management, September 2014.

Nr. 90 Grebel, Thomas; Stuetzer, Michael: Assessment of the Environmental Performance of European Countries over Time: Addressing the Role of Carbon, September 2014. 
Nr. 91 Emam, Sherief; Grebel, Thomas: Rising Energy Prices and Advances in Renewable Energy Technologies, July 2014.

Nr. 92 Budzinski, Oliver; Pannicke, Julia: Culturally-Biased Voting in the Eurovision Song Contest: Do National Contests Differ?, December 2014.

Nr. 93 Budzinski, Oliver; Eckert, Sandra: Wettbewerb und Regulierung, März 2015.

Nr. 94 Budzinski, Oliver; Feddersen, Arne: Grundlagen der Sportnachfrage: Theorie und Empirie der Einflussfaktoren auf die Zuschauernachfrage, Mai 2015.

Nr. 95 Pannicke, Julia: Abstimmungsverhalten im Bundesvision Song Contest: Regionale Nähe versus Qualität der Musik, Oktober 2015.

Nr.96 Budzinski, Oliver; Kretschmer, Jürgen-Peter: Unprofitable Horizontal Mergers, External Effects, and Welfare, October 2015.

Nr. 97 Budzinski, Oliver; Köhler, Karoline Henrike: Is Amazon The Next Google?, October 2015.

Nr. 98 Kaimann, Daniel; Pannicke, Julia: Movie success in a genre specific contest: Evidence from the US film industry, December 2015.

Nr. 99 Pannicke, Julia: Media Bias in Women's Magazines: Do Advertisements Influence Editorial Content?, December 2015.

Nr. 100 Neute, Nadine; Budzinski, Oliver: Ökonomische Anmerkungen zur aktuellen Netzneutralitätspolitik in den USA, Mai 2016.

Nr. 101 Budzinski, Oliver; Pannicke, Julia: Do Preferences for Pop Music Converge across Countries? - Empirical Evidence from the Eurovision Song Contest, Juni 2016.

Nr. 102 Budzinski, Oliver; Müller-Kock, Anika: Market Power and Media Revenue Allocation in Professonal Sports: The Case of Formula One, Juni 2016.

Nr. 103 Budzinski, Oliver: Aktuelle Herausforderungen der Wettbewerbspolitik durch Marktplätze im Internet, September 2016.

Nr. 104 Budzinski, Oliver: Sind Wettbewerbe im Profisport Rattenrennen?, Februar 2017.

Nr. 105 Budzinski, Oliver; Schneider, Sonja: Smart Fitness: Ökonomische Effekte einer Digitalisierung der Selbstvermessung, März 2017.

Nr. 106 Budzinski, Oliver; Pannicke, Julia: Does Popularity Matter in a TV Song Competition? Evidence from a National Music Contest, April 2017. 
Nr. 107 Budzinski, Oliver; Grusevaja, Marina: Die Medienökonomik personalisierter Daten und der Facebook-Fall, April 2017.

Nr. 108 Budzinski, Oliver: Wettbewerbsregeln für das Digitale Zeitalter - Die Ökonomik personalisierter Daten, Verbraucherschutz und die 9.GWBNovelle, August 2017. 